NBER WORKING PAPER SERIES

\title{
HEIGHT, SKILLS, AND LABOR MARKET OUTCOMES IN MEXICO
}

\author{
Tom Vogl \\ Working Paper 18318 \\ http://www.nber.org/papers/w18318 \\ NATIONAL BUREAU OF ECONOMIC RESEARCH \\ 1050 Massachusetts Avenue \\ Cambridge, MA 02138 \\ August 2012
}

I thank David Cutler, Larry Katz, Jeff Liebman, Duncan Thomas, Robert Willis, and seminar participants at Academia Sinica, Harvard, and the PAA meetings for helpful comments. This research was supported by the NSF Graduate Research Fellowship, the Multidisciplinary Program on Inequality and Social Policy (NSF IGERT Grant 0333403) and the NBER Aging Program (NIA Grant T32-AG000186). The views expressed herein are those of the author and do not necessarily reflect the views of the National Bureau of Economic Research.

NBER working papers are circulated for discussion and comment purposes. They have not been peerreviewed or been subject to the review by the NBER Board of Directors that accompanies official NBER publications.

(C) 2012 by Tom Vogl. All rights reserved. Short sections of text, not to exceed two paragraphs, may be quoted without explicit permission provided that full credit, including $\odot$ notice, is given to the source. 
Height, Skills, and Labor Market Outcomes in Mexico

Tom Vogl

NBER Working Paper No. 18318

August 2012

JEL No. I15,J24,O15

\title{
$\underline{\text { ABSTRACT }}$
}

Taller workers are paid higher wages. A prominent explanation for this pattern is that physical growth and cognitive development share childhood inputs, inducing a correlation between adult height and two productive skills: strength and intelligence. This paper explores the relative roles of strength and intelligence in explaining the labor market height premium in Mexico. While cognitive test scores account for a limited share of the height premium, roughly half of the premium can be attributed to the educational and occupational choices of taller workers. Taller workers obtain more education and sort into occupations with greater intelligence requirements and lower strength requirements, suggesting that the height premium partly reflects a return to cognitive skill.

\author{
Tom Vogl \\ Department of Economics \\ Princeton University \\ 363 Wallace Hall \\ Princeton, NJ 08544 \\ and NBER \\ tvogl@ princeton.edu
}




\section{Introduction}

In a wide range of economies-rich and poor, historical and contemporary-taller workers earn more than their shorter counterparts. ${ }^{1}$ Given the ubiquity of this relationship, researchers have devoted considerable effort to determining its origins, setting forth numerous hypotheses. One theory, popular for developing economies, posits that the returns to stature derive from the greater strength (and health) of taller individuals, which leads to a productivity advantage in economies that rely heavily on manual labor (Haddad and Bouis 1991; Thomas and Strauss 1997). For industrialized economies, explanations have been more varied, typically involving social-psychological pathways such as self esteem (Freedman 1979), social dominance (Hensley 1993), discrimination (Loh 1993; Hamermesh and Biddle 1994), and the social consequences of being short in adolescence (Persico et al. 2004). However, more recent research on the U.K. (Case and Paxson 2008) suggests that the height premium has much to do with a correlation between height and cognitive skill. Like the strength-based explanation, the cognitive skill theory is rooted in the idea that physical growth and skill development share many inputs-such as health, nutrition, and care in early life-so that for a given genetic height potential, people who achieve greater stature also tend achieve greater skill.

The extent to which cognitive skill (and human capital more generally) explains the height premium in contemporary developing economies is an open question. The reliance of these economies on manual labor does not necessarily bias them towards a solely strength-based height premium. Cognitive capacity improves entrepreneurship, the capacity to adapt to shocks, and general problem-solving skills, which may be valuable even entirely agrarian economies. For example, the literature on technology adoption in developing countries has emphasized the abilities of farmers to learn about the optimal uses of

\footnotetext{
${ }^{1}$ See, for example, Persico et al. (2004) and Case and Paxson (2008) on the U.S. and U.K.; Lundborg et al. (2009) on Sweden; Thomas and Strauss (1997) on Brazil; and Haddad and Bouis (1991) on the Philippines. The return to height was also high historically, for example among slaves in the antebellum American South (Margo and Steckel 1982) and among 19th century German workers (Komlos 1990).
} 
new seed varieties and fertilizers (Foster and Rosenzweig 1995; Duflo et al. 2011). Along these lines, Hanushek and Woessmann (2008) argue that cognitive skill is a fundamental determinant of individual income, the income distribution, and the rate of economic growth in developing countries.

This paper examines the relative roles of strength and intelligence in forging the link between height and labor market outcomes in Mexico, a country that straddles the line traditionally dividing economies intensive in manual labor from those intensive in skilled labor. The term "strength" is meant to encompass physical health, robustness, and endurance. The analysis takes advantage of rich data from the the Mexican Family Life Survey (MxFLS), which includes modules on health, anthropometry, cognitive skill, parental characteristics, and labor market outcomes. As the first nationally representative survey from a developing country to administer cognitive tests to working-age adults, the MxFLS provides a unique opportunity to unpack the height premium in a less industrialized setting.

Several existing studies explore the relative returns to strength and intelligence in developing country labor markets. Pitt et al. (forthcoming) focus on body mass endowments (rather than height) in Bangladesh, showing that larger men are more likely to engage in energy-intensive activities, while larger women are less likely. They argue that these sorting patterns are consistent with a high return to physical skill; body mass is more strongly correlated with strength for men than for women. Rosenzweig and Zhang (2012) complement these results in a study of Chinese twins, finding that female twins with higher birthweight attain more education, while male twins with higher birthweight develop greater adult body mass. On the other hand, Berhmann et al. (2009) use data from Guatemala to argue that brains, not brawn, have significant wage returns. ${ }^{2}$ Both studies follow in the tradition of an earlier paper by Thomas and Strauss (1997), which finds that wages are positively related to height, body mass, and nutrient intake among Brazilian men. Thomas

\footnotetext{
${ }^{2}$ Importantly, Behrmann et al.'s (2009) conclusions rest on quite strong exclusion restrictions. Their instruments for cognitive skill and body size include childhood proximity to a health post, class size at age 7, birth cohort, and parental characteristics.
} 
and Strauss document interesting heterogeneity in the elasticity of wages with respect to body size. In the market sector, height and earnings are most strongly correlated among the most educated workers, suggesting a role for cognitive skill. But in the self-employed sector, the correlation is strongest among the illiterate, who primarily engage in physical labor, suggesting a role for strength. ${ }^{3}$ Note that many of these studies' interesting results concern sectoral affiliation; Pitt et al. (forthcoming) study the sorting of workers across sectors, while Thomas and Strauss (1997) glean their conclusions from effect heterogeneity across sectors.

This paper also devotes much attention to the sectoral affiliations of taller and shorter workers. The paper begins with an exploration of the relationships linking height, cognitive skill, education, and earnings, but it then moves on to its primary contribution, an analysis of height-based occupational sorting. To avoid issues of endogenous labor force participation, the analysis sample only includes male workers, although unreported results for women are quite similar. The results indicate that each centimeter of height earns these men 2 percent higher wages, a premium similar to those observed in other developing countries but more than twice those observed in most wealthy countries. ${ }^{4}$ Childhood health conditions and parental socioeconomic status explain a substantial share of this height premium, but the premium remains statistically and economically significant even after adjustment for these background characteristics. Cognitive test scores account for only a limited part of the height premium, although the measured scores may provide either an overestimate or an underestimate of the role of cognitive skill. The test instrument is relatively crude, so its coefficient may be attenuated. At the same time, because survey respondents took the test in adulthood, their scores may in part reflect job-related opportunities to practice cognitive tasks, which would tend to (spuriously) inflate the role of cognitive skill. Regardless, the findings do indicate that roughly half of the premium can be attributed to the sorting of workers across skill groups or occupations.

\footnotetext{
${ }^{3}$ Thomas and Strauss (1997) also find that the returns to body mass are uniformly stronger among the illiterate.

${ }^{4}$ See the sources listed in footnote 1.
} 
The rest of the paper focuses on this sorting. Based on a new linkage of Mexican occupational categories to job characteristics from the U.S. Dictionary of Occupational Titles (DOT), the paper considers the skill requirements of occupations with greater concentrations of tall workers. In line with the evidence from industrialized countries, taller workers select into occupations with higher intelligence requirements and lower strength requirements. This result is consistent with a Roy (1951) model in which taller workers have a comparative advantage in intelligence-intensive tasks. Importantly, education mediates nearly all of the relationship between height and occupational choice; taller workers tend to have more education, and educated workers tend to work in skill-intensive occupations. The role of education has two natural interpretations. First, parents' propensities to invest in child health and education may be correlated, a hypothesis raised by both Haddad and Bouis (1991) and Strauss and Thomas (1997) as a caveat to their argument that the height premium reflects a return to strength. Second, the early-life conditions that promote growth in childhood also promote cognitive development, which may raise the productivity of educational investments. Either way, the data suggest a strong role for cognitive skill—or human capital more broadly—in explaining the earnings premium paid to taller workers.

The paper proceeds as follows. Section 2 provides a brief review of the literature on the early-life determinants of height and skill, and Section 3 fits this literature into a conceptual framework to understand the relationship between height and labor market outcomes. A description of the data sources follows in Section 4. Section 5 then reports the results of wage regressions, and Section 6 reports the results of occupational choice analyses. Section 7 concludes.

\section{Growth, Cognitive Development, and Adult Achievement}

Adult height reflects the interaction of genetic and environmental factors from the womb to adulthood (Tanner 1979). During this period, an individual experiences two phases of 
intense growth, the first during gestation and infancy—from ages zero to three-and the second during adolescence. Good nutrition and freedom from infection during these periods, particularly the first, are critical to achieving optimal growth. Apart from its direct effects on growth, nutritional deprivation increases young children's susceptibility to infection. Infection, in turn, inhibits nutrient absorption and appetite, leading to a "synergism" between nutrition and infection (Scrimshaw et al. 1968).

The prenatal and very early postnatal periods appear to be of particular importance for adult height. Early-life adversity may alter tissue differentiation and development in ways that boost short-run survival at the expense of long-run health (Barker 2001). A growing body of research indicates that deprivation during this period-whether inside or outside the womb-has lasting effects on stature. Among identical twins in Norway, those born with a 10 percent birthweight advantage over their twins gain an extra 0.6 centimeters in height by age 18 (Black et al. 2007). Results of this type extend as far as rural Indonesia, where Maccini and Yang (2009) show that women exposed to above average rainfall in their birth years attain significantly greater heights. ${ }^{5}$ In a similar vein, among French soldiers in the 19th and early 20th centuries, childhood exposure to the grape vine parasite phylloxera reduced adult height, presumably through a reduction in parental income (Banerjee et al. 2010).

Negative health and nutrition shocks, both in utero and in early childhood, have similarly detrimental effects on cognition and physical strength later in life. In industrialized countries, a large body of research has documented cognitive deficits among children born with low birth weight (Breslau 1995). ${ }^{6}$ The specific effects of low birth weight are not well-documented in developing countries, but randomized trials have confirmed the effects of nutrition on cognition in such settings (Grantham-McGregor 1995). ${ }^{7}$ Evidence

\footnotetext{
${ }^{5}$ Interestingly, Maccini and Yang do not find similar benefits of early-life rainfall for men.

${ }^{6}$ In Black et al.'s study of Norwegian twins, a 10 percent increase in birth weight increases age 18 IQ by roughly one third of a standard deviation. Richards et al. (2002) find similarly-sized associations among young British adults who were born with low birth weight.

${ }^{7}$ In one well-known trial in Jamaica (Grantham-McGregor et al. 1991), administration of milk-based formula to young stunted children led to substantial gains on developmental tests, especially when researchers
} 
linking early-life health and muscle strength in adulthood is somewhat rarer, but a number of studies in rich and poor countries have shown a positive relationship between birth weight and muscle strength over the lifecourse (Dodds et al. forthcoming).

Combined, these results suggest that superior health and nutrition promote both physical growth and cognitive development. ${ }^{8}$ Indeed, height is correlated with cognitive test scores in children from a range of settings. ${ }^{9}$ This association carries well into adulthood, as evidenced in Hawaii (Abbott et al. 1998), the U.K. (Richards et al. 2002; Case and Paxson 2008); urban Latin America (Maurer 2010); and China (Huang et al. 2011). Taller individuals' enhanced cognitive skills may also increase the productivity of schooling, which may explain the correlation between height and education, observed in such diverse settings as Brazil (Strauss and Thomas 1998), India (Perkins et al. 2010), Sweden (Magnusson et al. 2006), and the U.S. and U.K. (Case and Paxson 2010). Height is also associated with physical strength in adults (Tuvemo et al. 1999; Lundborg et al. 2009).

\section{Conceptual Framework}

The current knowledge on the co-evolution of body size, strength, and cognitive skill fits nicely into a theoretical framework in the tradition of Roy (1951). In a complementary line of work, Pitt et al. (forthcoming) and Rosenzweig and Zhang (2012) also use the Roy model to study strength and cognitive skill in developing economies. For tractability, they use the functional form assumptions of Ohnsorge and Trefler (2007) and derive predictions for gender and occupational segregation. In the framework below, I aim to conceptualize key issues in the relationship between height and labor market outcomes, rather than derive

coupled cognitive stimulation with nutritional supplementation.

${ }^{8}$ Height and intelligence may share common chemical antecedents, including insulin-like growth factor (Berger 2001) and thyroid hormone (Richards et al. 2002).

${ }^{9}$ Conditional on age, sex, and family background characteristics, the correlation of height and cognitive test scores is roughly 0.05-0.10 among both British children (Case and Paxson 2008) and Ecuadorian children (Paxson and Schady 2007). In a cohort of Peruvian children, severe stunting at age two is associated with a one standard deviation deficit in cognitive test scores at age nine (Berkman et al. 2002). In a cohort of Filipino children, moderate and severe stunting at age two are associated with a 0.25 and 0.6 standard deviation decline in cognitive test scores at age eight (Mendez and Adair 1999). 
analytic results. As such, I do not assume functional forms.

Let $h, v^{p}$, and $v^{c}$ denote a worker's height, physical ability (including strength, health, and robustness), and cognitive ability, respectively. For clarity of exposition, we treat $v^{p}$ and $v^{c}$ as endowments that are fixed after early childhood; when we specify the wage function below, we will allow workers to augment their cognitive ability endowments through investments after early childhood. The three worker traits have the following production functions:

$$
\begin{aligned}
h & =h\left(N ; B, D, X, \varepsilon_{h}\right) \\
v^{p} & =v^{p}\left(N ; B, D, X, \varepsilon_{p}\right) \\
v^{c} & =v^{c}\left(N ; B, D, X, \varepsilon_{c}\right)
\end{aligned}
$$

where $N$ denotes childhood nutrition and health inputs, $B$ denotes childhood background characteristics, $D$ denotes the childhood disease environment, $X$ is a vector of exogenous demographic controls, and $\left\{\varepsilon_{h}, \varepsilon_{p}, \varepsilon_{c}\right\}$ are mutually independent error terms. The three production functions share partial derivatives of the same sign with respect to $N, B$, and $D$. Thus, conditional on $X, h, v^{p}$, and $v^{c}$ are positively correlated.

Upon reaching adulthood, the worker faces a labor market with $J$ sectors, indexed $j$. The worker's potential wage in each sector is given by:

$$
w_{j}=w_{j}\left(v^{p}, v^{c}, S ; X, \varepsilon_{j}\right)
$$

where $S$ denotes schooling and the other variables are defined as before. For all sectors, the partial derivatives of wages with respect to $v^{p}, v^{c}, S$, and $E$ are positive.

The simplest formulation of the model would have the worker and his parents choose $\{N, S, j\}$ to maximize a utility function over parental consumption $(C)$ and the worker's wage in adulthood:

$$
U\left(C, w_{j}\left(v^{p}, v^{c}, S ; X, \varepsilon_{j}\right)\right)
$$


Maximization would then be subject to the following budget constraint:

$$
I=p_{C} C+p_{N} N+\left[p_{S}-\psi\left(v^{p}, v^{c} ; \varepsilon_{\psi}\right)\right] S
$$

where $I$ is parental income; $p_{C}, p_{N}$, and $p_{S}$ are the prices of parental consumption, child nutrition and health inputs, and schooling, receptively; and $\psi(\cdot)$ is the opportunity cost of schooling. The opportunity cost of schooling can be thought of as wage income from teenage employment.

This simple setup with no uncertainty delivers the main predictions of the paper. First, it leads to an unambiguously positive correlation between height and wages, working through the production functions for $h, v^{p}$, and $v^{c}{ }^{10}$ Second, if cognitive ability increases the productivity of schooling in all sectors $\left(\partial^{2} w_{j} / \partial v^{c} \partial S>0\right.$ for all $\left.j\right)$-as the literature on the returns to schooling typically assumes (Card 2001) - then taller individuals obtain more schooling. Third, if the sector-specific returns to cognitive ability are large and heterogeneous (relative to the returns to physical ability), then taller workers sort into sectors with higher returns to cognitive ability. At the same time, the fact that parents maximize their utility suggests a caveat; many of the same patterns may result from heterogeneity in parental income and preferences. Parents who invest more in their children's health may also invest more in their children's schooling, for reasons unrelated to the cross-partial $\partial^{2} w_{j} / \partial v^{c} \partial S$.

A more realistic version of the model would separate the decision process into three stages—nutrition, schooling, and sectoral choice-and would introduce environment, income, and labor market shocks at each stage. This setup would deliver similar predictions but would also allow for correlations between height and labor market outcomes after controlling for parental characteristics like income. In either case, the principal results derive from the fact that $h, v^{p}$, and $v^{c}$ share inputs.

\footnotetext{
${ }^{10}$ On average, taller workers hold an absolute advantage over shorter workers (in both physical and cognitive ability), so the envelope theorem implies that they will earn higher average wages after making their wage-maximizing choices.
} 
Much of the empirical analysis focuses on the sorting of workers across sectors, measured as occupations. Ideally, one would study both occupational choice and withinoccupation skill returns, to verify that taller workers indeed sort into occupations with high returns to both height and either cognitive or physical skill. However, within-occupation skill returns are difficult to estimate. The researcher observes only one realized wage per worker, rather than potential wages in every occupation. As a result, within-occupation estimates of based only on realized wages are inconsistent because sorting induces a negative correlation between the skill and the error term. With adequate panel data and structural assumptions, one can recover within-occupation skill returns (see, e.g., Gibbons et al. 2005). However, these methods require substantial movement of workers across occupations, and too few workers in the Mexican Family Life Survey change occupations between survey waves. As a result, I focus on occupational choice, and I then compare the observed occupational sorting with estimates of occupational skill requirements from the U.S. Dictionary of Occupational Titles.

\section{Data}

The analysis of height and labor market outcomes draws on data from the the Mexican Family Life Survey (MxFLS), a panel with two waves (so far) in 2002 and 2005. The MxFLS, a nationally representative household survey, included modules on household economic decisions and household demographic structure, as well as individual-level questions on labor market participation, self-reported health, schooling, and the living conditions that adults experienced while growing up. The survey administered a short cognitive test and also collected data on the heights and weights of all household members. To avoid sample selection issues arising from endogenous labor force participation, I employ data on men aged $25-65 .{ }^{11}$

\footnotetext{
${ }^{11}$ The sample restrictions have two important dimensions: age and gender. The gender restriction serves to simplify the interpretation of the results, without the complication of selection bias. Results for working women are very similar to the results presented here for men. The age restriction is also aimed to minimize
} 
To measure height and cognitive skill, I use standing height in centimeters and a cognitive test score based on the short-form Raven's Progressive Matrices test (Raven et al. 1983). ${ }^{12}$ The Raven test, which is intended to measure abstract reasoning, presents the subject with a series of patterns (called matrices), each with a missing element. ${ }^{13}$ For each matrix, the subject selects the missing element from a bank of eight candidates. In the MxFLS, the adult Raven test comprised 12 matrices. To obtain a composite measure of test performance, I sum the number of correct responses and then standardize them within sample to have a mean of zero and a standard deviation of one. In interpreting analyses of the Raven test score, two caveats are worthy of note. First, the test score measures accumulated cognitive skill over the lifecycle, reflecting early-life cognitive development, schooling, and cognitive reinforcement learning in adulthood. Second, with only 12 simple matrices on the Raven test, the test score is a noisy measure of cognitive skill. Both caveats suggest that the Raven score is not an ideal measure of $v^{c}$ from the theoretical framework in Section 3. The first caveat might lead us to overstate the role of early-life influences on cognitive ability because of cognitive reinforcement. On the other hand, the second caveat might lead us to understate it because of attenuation bias.

I measure hourly earnings using an individually-administered survey module on labor market outcomes over the previous year. Wages are notoriously difficult to measure in developing countries, given the prevalence of informal contracting and self-employment. However, the MxFLS posed a detailed set of questions that enable the calculation of hourly earnings for a wide variety of individuals, including farmers and small business owners. Every respondent answered questions about the number of weeks worked in his or her main job, the number of hours worked per week, and post-tax labor earnings. Nonselection bias. In Mexico, many begin working well before age 25, but the inclusion of individuals under 25 would induce sample selection biases stemming from schooling decisions. 65 is an appropriate age ceiling for working adults, but it is also in part determined by the data; the MxFLS did not gather detailed data on individuals above this age.

${ }^{12}$ I trim the top and bottom 0.5 percent of the height distribution to reduce the influence of outliers.

${ }^{13}$ The Raven test exhibits high 'g-loading,' meaning that its score correlates strongly with general factor intelligence, a unidimensional variable that many cognitive psychologists hypothesize underlies cognitive skills (Carroll 1993). 
working individuals reported on their previous jobs if they worked in the previous year. I compute hourly earnings for individuals who reported working 20 or more hours per week regularly over the previous year. For wage earners, the survey collected data on earnings both over the previous month and over the previous year. The appendix describes the algorithm used to reconcile differences between the monthly and annual reports.

Occupational classifications are crucial to the analysis. For the wage analysis, I use the 19-category Mexican Classification of Occupations (MCO), but one cannot merge the MCO to measures of occupational skill requirements from the Dictionary of Occupational Titles (DOT). As an alternative, I use the nine civilian occupations in the coarser International Standard Classification of Occupations (ISCO), which can be matched to both the Mexican and the U.S. job classification systems. ${ }^{14}$ From England and Kilbourne's (1988) job characteristics file, which maps DOT measures to the three-digit detailed occupational classification of the 1980 U.S. Census, I assign measures of occupational skill requirements to workers in the 1980 U.S. Census (Ruggles et al. 2008). Then, using the 1980 U.S. distribution of occupations, I then aggregate the detailed occupation categories up to the ninecategory ISCO. This procedure assumes that the distribution of detailed occupations and relative skill requirements within each broad ISCO category is the same in the 1980 U.S. and 2002 Mexico. Although these assumptions are unlikely to hold exactly, the aggregation procedure can nonetheless provide a useful guide to the skill content of height-based occupation sorting.

In the analysis of the DOT, I use the "intelligence aptitude" and "strength" intensities of each occupation as measures of cognitive and physical skill requirements. Alternative measures from the DOT (such as "numerical skills" and "physical demands") yield results similar to those reported below. Some of the results are more interpretable with a binary categorization of occupational skill requirements, so that workers select either the "brains" sector or the "brawn" sector. Appendix Figure 1 plots intelligence aptitude requirements

\footnotetext{
${ }^{14}$ Most of the two-digit MCO categories map perfectly onto the ISCO, but three do not: worker in personal establishments; worker in domestic services; and protection, monitoring and armed forces. In the analysis of skill requirements, I omit these occupation groups.
} 
against strength requirements for the civilian occupations in the ISCO, revealing that the occupations divide naturally into "brains" and "brawn" sectors. I define the two sectors as indicated in the figure.

In all analyses, I only use data on individuals who were in the 2002 baseline survey wave. I use survey weights to estimate population regression parameters, and I cluster standard errors at the primary sampling unit (PSU) level. ${ }^{15}$ Because I only study original members of the 2002 cohort, I use the 2002 survey weights and the 2002 PSUs. ${ }^{16}$ If an individual has two height measurements, I average them. ${ }^{17}$ If an individual has two measurements for any other covariates (particularly the cognitive test and childhood conditions), I use the first measurement. ${ }^{18}$

Table 1 presents summary statistics for selected characteristics, with one column for each of the two samples used in the study. Because earnings are missing for many workers, the sample for the earnings analysis is smaller than the sample for the occupational choice analysis. ${ }^{19}$ On average, workers in both samples are about 40 years old, a meter and a twothirds tall, and fifteen percent indigenous, and they have eight years of education. ${ }^{20}$ In the earnings sample, average hourly earnings is roughly 20 Mexican pesos (or US\$2). In the occupation sample, 90 percent of workers are in "brawn" occupations rather than "brains" occupations.

\footnotetext{
${ }^{15}$ Because the paper aims to describe the relationship between height and labor market outcomes at the national level, the use of survey weights is appropriate (Deaton 1997).

${ }^{16}$ The MxFLS does not provide survey weights for the 2005 wave.

${ }^{17}$ Slightly fewer than 8 percent of the male respondents to the employment module had missing heights. The probability of a missing value for height was increasing in education: each year of education reduces the probability of height measurement by 0.36 percentage points $(p$-value $<0.01)$. As a result, my estimates of the height premium may be biased slightly downward.

${ }^{18}$ Use of the first measurement is important for the cognitive test, since the same test questions were administered in both survey waves.

${ }^{19}$ In Section 7 below, I show that the two samples show similar relationships between height and a measure of imputed earnings based on the worker's occupation, industry, and education level.

${ }^{20}$ Respondents with post-secondary education did not reply to questions regarding years of schooling, so I impute years of schooling for them using data from the 2000 Mexican Census. I divide individuals with post-secondary education into sex-specific, five-year age groups, and I then calculate the average number of years of post-secondary schooling within each cell. I then merge these data with the MxFLS on the basis of sex and age group. The five-year age groups in the 2000 census tabulations run from 25 to 64 , so they do not perfectly match the cohorts in the MxFLS, who were aged 25-65 in the year 2002. However, all of the cell means from the census are extremely close to four years, so this mismatch should not bias the results.
} 


\section{The Returns to Height: Graphical Evidence}

For four outcomes-log hourly earnings, educational attainment, cognitive test scores, and self-reported health-Figure 1 documents the returns to height graphically. Each panel shows local linear regression of an adult outcome on height. The solid curves correspond to the regression function estimates, while the dotted curves bound pointwise 95 percent confidence intervals.

Height bestows advantages in cognitive skill, education, health, and earnings. The top left panel of Figure 1 shows a positive, monotonic relationship between height and earnings. A increase in height by ten centimeters is associated with an increase in wages by roughly one quarter of a log point, implying a semi-elasticity of 2-3 percent per centimeter. The remaining panels of Figure 1 reveal that taller individuals enjoy other benefits. For every ten centimeters of height, educational attainment rises more than one year, cognitive test scores increase by 40 percent of a standard deviation, and self-reported health status improves by just short of 20 percent of a standard deviation. All regression functions are precisely estimated, showing no clear evidence of nonlinearity.

One possible interpretation for the relationships in Figure 1 is ethnic heterogeneity. This theory posits that indigenous people are both shorter and more disadvantaged, but for separate reasons. ${ }^{21}$ However, Figure 2 reveals that ethnic heterogeneity does not explain the strong relationships in Figure 1. The left-hand panel of Figure 2 plots separate height-earnings profiles for workers with indigenous and non-indigenous backgrounds; both curves are steeply positive. Notably, the measure of ethnicity is self-reported and as such may be measured with error, so Figure 2 does not completely rule out ethnic heterogeneity. Nonetheless, the steepness of the curve for indigenous workers suggests that ethnic heterogeneity is not to blame. The right-hand panel of Figure 2 disaggregates the sample by sector of birth instead of ethnicity. Again, both curves slope upwards, with a steeper curve for workers born in rural areas.

\footnotetext{
${ }^{21}$ For instance, indigenous people may be genetically short and historically persecuted.
} 
Both indigenous and rural-born workers have steeper relationships between height and earnings. Two theories are particularly natural for interpreting the steeper curves for more disadvantaged groups. First, the variance of the non-genetic determinants of height may be higher for disadvantaged groups; nutritional inputs and the local disease environment may be more volatile. In a simple statistical model in which height is a proxy for childhood conditions, the estimated return to height is higher when the variance of childhood conditions is larger. ${ }^{22}$ Second, the returns to skill may be higher for individuals from disadvantaged backgrounds, who may have more to gain from migration. In the figures, one can see that indigenous and rural workers are most disadvantaged at short heights. However, at taller heights, these workers are indistinguishable from their more advantaged counterparts.

More broadly, the non-parametric regressions in Figure 1 suggest several skill-based explanations for the covariance of height and earnings. One possibility, in the spirit of Case and Paxson (2008), is that the inputs to physical growth in childhood coincide with the inputs to cognitive development, so that height is merely a proxy for intelligence. This could also explain why educational attainment rises with height, if schooling and cognitive ability are complimentary. A competing account, more in line with the previous literature on developing countries, would emphasize the negative association of short stature with health status and strength (Tuvemo et al. 1999; Lundborg et al. 2009). Note, however, that the positive associations of height with cognitive skill, education, and health status still may reflect unobserved family-level heterogeneity-in parents' tendency to invest in all forms of child development, for example-which could just as easily explain the heightearnings gradient.

\footnotetext{
${ }^{22}$ Suppose $h=\alpha^{h}+\beta^{h} z+\eta$ and $\ln w=\alpha^{w}+\beta^{w} z+\zeta$, where $h$ is height, $w$ is wages, and $z$ is childhood conditions. Then the slope coefficient from a regression of the log wage on height converges in probability to $\frac{\beta^{w}}{\beta^{h}}\left(1+\frac{\sigma_{\eta}^{2}}{\beta_{z}^{2} \sigma_{z}^{2}}\right)^{-1}$. Thus, the probability limit of the coefficient increases in $\sigma_{z}^{2}$. In words, earnings differences between tall and short workers are greatest when childhood conditions are more variable.
} 


\section{Height and Earnings}

Table 2 reports the main regressions of the logarithm of hourly earnings on height. Much of the literature on industrialized settings (e.g., Persico et al. 2004; Case and Paxson 2006) has analyzed height in levels, leading to semi-elasticities, whereas the literature on developing settings (e.g., Haddad and Bouis 1991; Thomas and Strauss 1997) has used the logarithm of height, leading to elasticities. For conciseness, I focus exclusively on semi-elasticities, but unreported results using elasticities show similar patterns. All regressions control for demographic characteristics including age and indigenous group membership. Column (1) runs a regression with just the demographic control variables; the remaining columns add height and a variety of other covariates. Comparing the adjusted $R$-squared terms from columns (1) and (2), one learns that the inclusion of height improves the fit of the basic model by 60 percent. Relative to ethnicity and age, height has substantial explanatory power for earnings.

The coefficient on height in column (2), 0.023, implies that each centimeter in height is associated with wage gains of 2.3 percent. This result contrasts findings from the United States and Britain (e.g., Case and Paxson 2010), which put the semi-elasticity at roughly 2 percent per inch of height (or 0.8 percent per centimeter). As Section 5 pointed out in discussing heterogeneity by ethnicity or birthplace, the difference has two interpretations. First, it may stem from differences in skill returns or the relationships linking child health with adult height and skill. Second, it may be the result of a higher variance of the nongenetic determinants of height in Mexico, which would bias upward the return to height.

Columns (3)-(5) add the Raven score and a vector of childhood covariates to the regression. The inclusion of the cognitive test score results in a 13 percent reduction in the height premium. Although this change is relatively small, a generalized Hausman test that allows for clustering indicates that the fall in the height premium is statistically significant $(p<0.01)$. Furthermore, the coefficient estimate is probably attenuated. Despite past emphasis by (some) cognitive scientists on the existence of a unidimensional factor underlying 
intelligence, cognitive skill is in fact multifaceted, so one cannot expect an analysis to fully identify its effects with a single, 12-question matrices test. At the same time, insofar as high-paying work reinforces workers' cognitive skills, a cognitive test taken in adulthood may overstate the role of cognitive skill.

Meanwhile, columns (4) and (5) show that childhood conditions explain a substantial part of the returns to height and cognitive skill. The vector of childhood conditions is fairly comprehensive, including the father's first job, the father's and mother's education, access to piped water and sanitation at age 12, and urban birthplace. In the fullest model (column [5]), the vector's inclusion reduces the coefficient on height to 0.014 and the coefficient on the Raven score to 0.094 . The coefficients on the childhood covariates are jointly significant at the 0.1 percent level, and the model's explanatory power is now quite high, with an $R$-squared of 0.16 .

Table 3 explores heterogeneity in these results by ethnicity and birthplace, confirming the patterns in the non-parametric regressions in Figure 2. In particular, column (1) reveals higher returns to height among indigenous workers and among workers born in the countryside. The Raven score explains a larger share of the height premium among the same two groups of workers. On the other hand, childhood covariates explain a larger share of the premium among the non-indigenous and among those born in cities. This result may have to due with the larger variances of the observable childhood covariates in these more advantaged groups of workers. Thus, the higher height premium of workers from disadvantaged backgrounds may be due to greater idiosyncratic volatility in living conditions, rather than variation in longer-term, observable living conditions.

Returning to the full sample, Table 4 investigates whether the returns to height accrue within or between occupation and education groups. This is strictly an accounting exercise; occupation and education should be interpreted as choice variables. The inclusion of either occupation dummies or educational attainment (as a continuous covariate) cuts the estimated height premium approximately in half (compared with column [1]), im- 
plying that a large part of the height premium is attributable to the higher educational attainment of taller workers or to their sorting into higher-paying occupations. ${ }^{23}$

\section{Height and Occupational Choice}

The results of the previous section imply that sorting across occupations contributes to the returns to height. This finding is interesting, especially in light of Case and Paxson's (2006) evidence from the United States that taller individuals sort into occupations with greater cognitive demands. As discussed in Section 3, if cognitive ability explains the height premium, then the tallest workers will sort into the most cognitively demanding occupations. This section assesses height-based occupational selection in two steps. First, it assesses whether "taller" occupation groups have higher intelligence aptitude or strength requirements. Second, it explores the roles of cognitive skill, childhood conditions, and educational choices in explaining height-based selection into "brains" or "brawn" occupations. Throughout, it uses a full sample of workers, rather than restricting the sample to workers with non-missing hourly earnings. The full sample exhibits sectoral sorting that is similar to the earnings sample in Section 6. Appendix Table 1 assigns each worker the mean hourly earnings of her occupation-industry-education cell in the 2000 Mexican census, and then regresses the logarithm of this sectoral earnings score on height and demographic characteristics. The coefficients on height in the full sample and the earnings sample are quite close.

For the first step of the occupational choice analysis, I follow Case and Paxson (2006) in estimating a multinomial logit regression of occupation category (as classified by the ISCO) on height:

$$
\ln \left[\frac{p_{i j}}{p_{i 0}}\right]=\gamma_{j} h_{e i g h t}+X_{i}^{\prime} \Gamma_{j}, j>0
$$

where $p_{i j}$ is the probability that worker $i$ selects an occupation in category $j$, and $j=0$ cor-

\footnotetext{
${ }^{23} \mathrm{~A}$ Mincer-style earnings regression that omits height yields a return to schooling of 7.7 percent.
} 
responds to the professional occupation category. To reduce the dimensionality of the likelihood maximization problem, I restrict $X_{i}$, the vector of control variables, to include only a constant term, ethnicity, age, and a squared term in age. After estimating the logit regressions, I plot occupational skill measures from the DOT against each occupation category's relative risk ratio on height $\left(e^{\gamma_{j}}\right)$. An occupation category's relative risk ratio measures the association between height and the risk of selection into that occupation category, relative to the professional occupation category. By plotting each occupation category's cognitive and physical skill intensities against its relative risk ratio on height, one can infer whether physical or cognitive skill drives height-based occupational sorting.

The results, which appear in Figure 3, indicate that taller men and women systematically select into occupations with larger intelligence aptitude demands and smaller strength demands. The plots are surprisingly similar to the occupational sorting patterns that arise in industrialized countries (Case and Paxson 2006). Combined with Table 4, we reach the conclusion that nearly half of Mexico's height premium can be attributed to the sorting of taller workers into occupations intensive in cognitive skill. Seen through the lens of the theoretical framework of Section 3, this result suggests that the return to cognitive ability (and human capital more broadly) drives a substantial part of the height premium.

Again, these results are not merely driven by ethnic or birthplace heterogeneity. Figures 4 and 5 draw the same plots by ethnicity and birthplace. The same patterns emerge, with "taller" occupations exhibiting higher average intelligence requirements and lower average strength requirements. Perhaps surprisingly, the patterns appear quite similar for indigenous, non-indigenous, rural-born, and urban-born workers.

To further understand these patterns, Table 5 performs an analysis of occupational choice that is analogous to Table 2's analysis of the height premium. The table reports marginal effects from logit regressions in which the dependent variable equals 0 for a "brains" occupation and 1 for a "brawn" occupation. The marginal effects are multiplied by 100 , so that a marginal effect of 1 corresponds to a 1 percentage point increase in the 
probability of working in a "brawn" occupation. Each column adds a different set of covariates to the basic specification.

The associations of height with cognitive skill, childhood conditions, and educational investments account for the lion's share of the decreased likelihood of taller workers to select into manual occupations. Column (1) indicates that a centimeter of height decreases the probability of working in a "brawn" occupation by 0.63 percentage points. This association falls to 0.34 percentage points with inclusion of childhood covariates (column [2]), and further to 0.26 percentage points with the addition of the Raven score (column [5]). Strikingly, the roles of cognitive skill and childhood conditions pale in comparison to that of educational attainment. In columns (3) and (6), the inclusion of educational attainment as covariate all but eliminates the negative relationship between height and manual labor. The logit coefficients on height remain statistically significant, but they are an order of magnitude smaller than before the inclusion of education as a covariate. That is to say, the educational investments of taller workers almost entirely explain their selection into more lucrative, more skilled occupations. Of course, these education investments have antecedents in cognitive ability and childhood conditions. Regardless, the results suggest that most of the relationship between height and occupational choice in adulthood is set before labor market entry.

\section{Conclusion}

Despite the universality of the association between height and labor market outcomes, conventional wisdom holds that its sources differ widely by setting. This paper shows that the origins of the height premium in developing and industrialized economies may be more similar than was previously thought. Much of the height premium accrues across broad occupation and schooling categories. As with Americans and Britons (Case and Paxson 2006), taller Mexicans sort into occupations with greater cognitive skill requirements and lower physical strength requirements, a pattern almost entirely explained by their greater 
educational attainment. Cognitive test scores and childhood conditions account for some of the higher wages and "brainier" occupations of taller workers. These results contribute to previous work on the relative roles of brains and brawn in the link between body size and labor market outcomes in developing countries (Thomas and Strauss 1997; Behrmann et al. 2011; Pitt et al. forthcoming; Rosenzweig and Zhang 2012).

The occupational sorting identified here may appear to be at odds with the results of Thomas and Strauss (1997), which show a higher height premium among the self-employed than among wage laborers. Thomas and Strauss interpret this difference as possible evidence for a strength-based height premium, given the tendency of the self-employed to engage in manual labor. In fact, unreported analyses reveal similar patterns in the Mexican data, with a higher height premium among the self-employed. But height is also negatively associated with self-employment, which suggests that the estimates for the self-employed may suffer from selection bias.

Setting aside the relative importance of brains and brawn, the paper has not explored the possible role of noncognitive skills (Bowles et al. 2001; Heckman et al. 2006). Using data from Sweden, Lundborg et al. (2009) show that height is correlated with measures of noncognitive ability and estimate that this correlation explains a non-negligible share of the height premium. The role of noncognitive ability in explaining the height premium in developing economies is a fruitful topic for future research.

Whatever the explanation for the height premium, it lays bare the profound effects of early-life conditions on later-life outcomes in school and in the labor market. In Mexico as elsewhere, the children of better-off parents experience superior physical growth and cognitive development. These dynamics may play an instrumental role in the intergenerational transmission of economics status. Research that disentangles the mechanisms underlying these relationships-including the returns to height-will help guide policies aimed at improving health and expanding the capability sets of young individuals as they reach adulthood. 


\section{Appendix: Reconciliation of Annual and Monthly Earnings}

As described in Section 4 of the text, the Mexican Family Life Survey (MxFLS) includes data on both monthly and annual earnings for wage earners. These data sometimes coincided, but in many cases they did not correspond perfectly. This short appendix describes the algorithm used to reconcile any differences and produce a measure of hourly earnings.

For workers employed in the market sector, I used the following procedure. First, some respondents simply reported annual income as twelve times their monthly income, without any adjustment for weeks worked. For individuals in this group who worked at least 48 weeks in their main occupations over the previous year, I used annual earnings, dividing by the product of weeks per year and hours per week. For individuals who worked less than 48 weeks, I used the monthly data, dividing by 4.35 times hours per week. I repeated this process for any individuals whose reported monthly earnings multiplied by twelve lay within 90 to 110 percent of their reported annual earnings. For remaining individuals, if the implied hourly wage from the monthly earnings report was within 20 percent of the implied hourly wage from the annual data, I averaged the two. From here, I settled any remaining discrepancies in individuals who worked less than 48 weeks by using the monthly data. Among discrepant individuals who worked more than 48 weeks, I discarded values that implied hourly earnings of greater than 200 pesos or less than 1 peso, which correspond to the top and bottom 0.5 percent of the wage distribution from census data. Finally, if remaining discrepant observations were professionals, technical workers, or directors, I used annual data. For the remaining occupations, I used monthly earnings.

For self-employed workers, I followed the same procedure, except that in the final step, I used monthly earnings for all workers, regardless of occupation. 


\section{References}

Abbott, Robert D., Lon R. White, G. Webster Ross, Helen Petrovitch, Kamal H. Masaki, David A. Snowdon, and J. David Curb. (1998). "Height as a Marker of Childhood Development and Late-Life Cognitive Function: The Honolulu-Asia Aging Study." Pediatrics 102(3): 602-9.

Banerjee, Abhijit, Esther Duflo, Gilles Postl-Vinay, and Tim Watts. (2010). "Long-Run Health Impacts of Income Shocks: Wine and Phyllozera in Nineteenth-Century France." Review of Economics and Statistics 92(4): 714-728.

Barker, David J.P., ed. (2001). Fetal Origins of Cardiovascular and Lung Disease. New York: Marcel Dekker, Inc.

Behrmann, Jere R., John Hoddiott, John A. Maluccio, and Reynaldo Martorell. (2009). "Brains versus Brawn: Labor Market Returns to Itellectual and Health Human Capital in a Poor Developing Country." Middlebury College Economics Discussion Paper No. 0907.

Berger, Abi. (2001). "Insulin-Like Growth Factor and Cognitive Function." British Medical Journal 322:203.

Berkman, Douglas S., Andres G. Lescano, Robert H. Gillman, Sonia L. Lopez and Maureen M. Black. (2002). "Effects of Stunting, Diarrhoeal Disease, and Parasitic Infection During Infancy on Cognition in Late Childhood: A Follow-Up Study." Lancet 359: 565-571.

Black, Maureen M. (2003). “Micronutrient Deficiencies and Cognitive Functioning." Journal of Nutrition 133(11 S2): 3927S-3931S.

Black, Sandra E., Paul J. Devereux, and Kjell G. Salvanes. (2007). "From the Cradle to the Labor Market? The Effect of Birth Weight on Adult Outcomes." Quarterly Journal of Economics 122(1): 409-439.

Bowles, Samuel, Herbert Gintis, and Melissa Osborne. (2001). "The Determinants of Earnings: A Behavioral Approach." Journal of Economic Literature 39(4): 1137-76.

Breslau, Naomi. (1995). "Psychiatric Sequelae of Low Birth Weight." Epidemiologic Reviews 17: 96-106.

Caldwell, John C. (1979). "Education as a Factor in Infant Mortality Decline: An Examination of Nigerian Data." Population Studies 3(3): 201-228.

Carroll, John B. (1993). Human Cognitive Abilities: A Survey of Factor Analytic Studies. Cambridge: Cambridge University Press. 
Case, Anne, and Christina Paxson. (2006). "Stature and Status: Height, Ability, and Labor Market Outcomes." Cambridge, MA: NBER. Working Paper No. 12466.

Case, Anne, and Christina Paxson. (2008). "Stature and Status: Height, Ability, and Labor Market Outcomes." Journal of Political Economy 116(3): 499-532.

Case, Anne, and Christina Paxson. (2010). "Causes and Consequences of Early Life Health." Demography 47(Supplement): 65-85.

Dodds, Richard, H.J. Denison, G. Ntani, R. Cooper, C. Cooper, A.A. Sayer, and J. Baird. (Forthcoming). "Birth Weight and Muscle Strength: A Systematic Review and MetaAnalysis." Journal of Nutrition, Health \& Aging.

Deaton, Angus. (1997). The Analysis of Household Surveys: A Microeconometric Approach to Development Policy. Baltimore, MD: Johns Hopkins University Press.

Duflo, Esther. (2001). "Schooling and Labor Market Consequences of School Construction in Indonesia: Evidence from an Unusual Policy Experiment." American Economic Review 91(4): 795-813.

Duflo, Esther, Michael Kremer, and Jon Robinson. (Forthcoming). "Nudging Farmers to Use Fertilizer: Theory and Experimental Evidence from Kenya." American Economic Review.

England, Paula, and Barbara Kilbourne. (1988). "Occupational Measures from the Dictionary of Occupational Titles for 1980 Census Detailed Occupations" [Computer file]. Richardson, TX: Paula England and Barbara Kilbourne [producers]. Ann Arbor, MI: Inter-university Consortium for Political and Social Research [distributor].

Foster, Andrew D. and Mark R. Rosenzweig. (1995). "Learning by Doing and Learning from Others: Human Capital and Technical Change in Agriculture." Journal of Political Economy 103(6): 1176-1209.

Freedman, Daniel G. (1979). Human Sociobiology. New York: Free Press.

Grantham-McGregor, Sally M. (1995). "A Review of Studies of the Effect of Severe Malnutrition on Mental Development." Journal of Nutrition 125(Supplement): 2238 S.

Grantham-McGregor, Sally M., C.A. Powell, S.P. Walker, and J.H. Himes. (1991). “Nutritional Supplementation, Psychosocial Stimulation, and Mental Development of Stunted Children: The Jamaican Study." Lancet 1991 338: 1-5.

Haddad, Lawrence J. and Howarth E. Bouis. (1991). "The Impact of Nutritional Status on Agricultural Productivity: Wage Evidence from the Philippines." Oxford Bulletin of Eco- 
nomics and Statistics 53: 45-68.

Hamermesh, Daniel S., and Jeff E. Biddle. (1994). "Beauty and the Labor Market." American Economic Review 84(5): 1174-1194.

Hanushek, Eric A., and Ludger Woessmann. 2008. "The Role of Cognitive Skills in Economic Development." Journal of Economic Literature 46(3): 607-68.

Heckman, James J., Jora Stixrud, and Sergio Urzua. (2006). "The Effects of Cognitive and Noncognitive Abilities on Labor Market Outcomes and Social Behavior." Journal of Labor Economics 24(3): 411-82.

Hensley, Wayne E. (1993). "Height as a Measure of Success in Academe." Psychology: A Journal of Human Behavior 30: 40-46.

Huang, Wei, Xiaoyan Lei, Geert Ridder, John Strauss, and Yaohui Zhao. (2012). "Health, Height, Height Shrinkage and SES at Older Ages: Evidence from China." Mimeo, Harvard University.

Komlos, John. (1990). "Height and Social Status in Eighteenth-Century Germany." Journal of Interdisciplinary History 20: 607-621.

Liebenstein, Harvey. (1957). Economic Backwardness and Economic Growth. New York: John Wiley.

Loh, Eng Sang. (1993). “The Economic Effects of Physical Appearance." Social Science Quarterly 74: 420-438.

Lundborg, Petter, Paul Nystedt, and Dan-Olof Rooth. (2009). "The Height Premium in Earnings: The Role of Cognitive Ability and Physical Strength." IZA Working Paper 4266.

Maccini, Sharon, and Dean Yang. (2009). "Under the Weather: Health, Schooling, and Economic Consequences of Early-Life Rainfall." American Economic Review, 99(3): 1006-26.

Margo, Robert, and Richard H. Steckel. (1982). "The Height of American Slaves: New Evidence on Slave Nutrition and Health." Social Science History 6: 516-38.

Magnusson, Patrik K.E., Finn Rasmussen, and Ulf B. Gyllensten. (2006). “Height at Age 18 Years is a Strong Predictor of Attained Education Later in Life: Cohort Study of Over 950000 Swedish Men." International Journal of Epidemiology 35:658-663.

Maurer, Jurgen. (2010). “Height, Education and Cognitive Function at Older Ages: International Evidence from Latin America and the Caribbean." Economics and Human Biology 8(2): 168-176. 
Mendez, Michelle A., and Linda S. Adair. (1999). "Severity and Timing of Stunting in the First Two Years of Life Affect Performance on Cognitive Tests in Late Childhood." Journal of Nutrition 129(8): 1555-1562.

Ohnsorge, Franziska, and Daniel Trefler. (2007). "Sorting it Out: International Trade with Heterogeneous Workers." Journal of Political Economy 115(5): 868-892.

Paxson, Christina, and Norbert Schady. (2007). "Cognitive Development among Young Children in Ecuador: The Roles of Wealth, Health, and Parenting." Journal of Human Resources 42: 49-84.

Perkins, Jessica M., Kashif T. Khan, George Davey Smith, and S.V. Subramanian. (2011). "Patterns and Trends of Adult Height in India in 2005-2006." Economics and Human Biology 9(2): 184-193.

Persico, Nicola, Andrew Postlewaite, and Daniel Silverman. (2004). "The Effect of Adolescent Experience on Labor Market Outcomes: The Case of Height." Journal of Political Economy 112: 1019-1053.

Pitt, Mark M., Mark R. Rosenzweig, and Nazmul Hassan. (Forthcoming). "Human Capital Investment and the Gender Division of Labor in a Brawn-Based Economy." American Economic Review.

Raven, J.C., J.H. Court, and J. Raven. (1983). Manual for Raven's Progressive Matrices and Vocabulary Scales. London: Lewis.

Richards, Marcus, Rebecca Hardy, Diana Kuh, and Michael E.J. Wadsworth. (2002). "Birthweight, Postnatal Growth and Cognitive Function in a National U.K. Birth Cohort." International Journal of Epidemiology 31: 342-48.

Rosenzweig, Mark R., and Junsen Zhang. (2012). “Economic Growth, Comparative Advantage, and Gender Differences in Schooling Outcomes: Evidence from Birthweight Differences of Chinese Twins." Mimeo, Yale University.

Roy, Andrew D. (1951). "Some Thoughts on the Distribution of Earnings." Oxford Economic Papers 3(2): 135-46.

Ruggles, Steve, Matthew Sobek, and Trent Alexander, et al. (2008). Integrated Public Use Microdata Series: Version 4.0 [Machine-readable database]. Minneapolis, MN: Minnesota Population Center [producer and distributor]. Online: http://usa.ipums.org/.

Scrimshaw, Nevin S., Carl E. Taylor, and John E. Gordon. (1968). "Interactions of Nutrition and Infection." Geneva: World Health Organization. WHO Monograph Series No. 57. 
Silventoinen, Karri, Jaakko Kaprio, and Eero Lahelma. (2000). “Genetic and Environmental Contributions to the Association Between Body Height and Educational Attainment: A Study of Adult Finnish Twins." Behavior Genetics 30(6): 477-485.

Silventoinen, Karri, Danielle Posthuma, Toos Cem van Beijsterveldt, Meike Bartels, and Dorret I. Boomsma. (2006). "Genetic Contributions to the Association Between Height and Intelligence: Evidence from Dutch Twin Data from Childhood to Middle Age." Genes, Brain and Behavior 5: 585-595.

Silventoinen, Karri, Patrik K.E. Magnusson, Per Tynelius, Jaakko Kaprio, and Finn Rasmussen. (2008). "Heritability of Body Size and Muscle Strength in Young Adulthood: A Study of One Million Swedish Men." Genetic Epidemiology 32: 341-349.

Strauss, John and Duncan Thomas. (1998). "Health, Nutrition, and Economic Development." Journal of Economic Literature 36(2): 766-817.

Sundet, Jon Martin, Kristian Tambs, Jennifer R. Harris, Per Magnus, and Tore M. Torjussen. (2005). "Resolving the Genetic and Environmental Sources of the Correlation Between Height and Intelligence: A Study of Nearly 2600 Norwegian Male Twin Pairs." Twin Research and Human Genetics 7:1-5.

Tanner, James M. (1979). "A Concise History of Growth Studies from Buffon to Boas." In Frank Falkner and James M. Tanner, eds., Human Growth, Volume 3: Neurobiology and Nutrition. New York: Springer, pp. 515-93.

Thomas, Duncan and John Strauss. (1997). "Health and Wages: Evidence on Men and Women in Urban Brazil." Journal of Econometrics 77(1): 159-185.

Tuvemo, Torsten, Björn Jonsson, and Ingemar Persson. (1999). "Intellectual and Physical Performance and Morbidity in Relation to Height in a Cohort of 18-Year-Old Swedish Conscripts." Hormone Research 52: 186-191. 
Figure 1: The Returns to Height, Various Outcomes
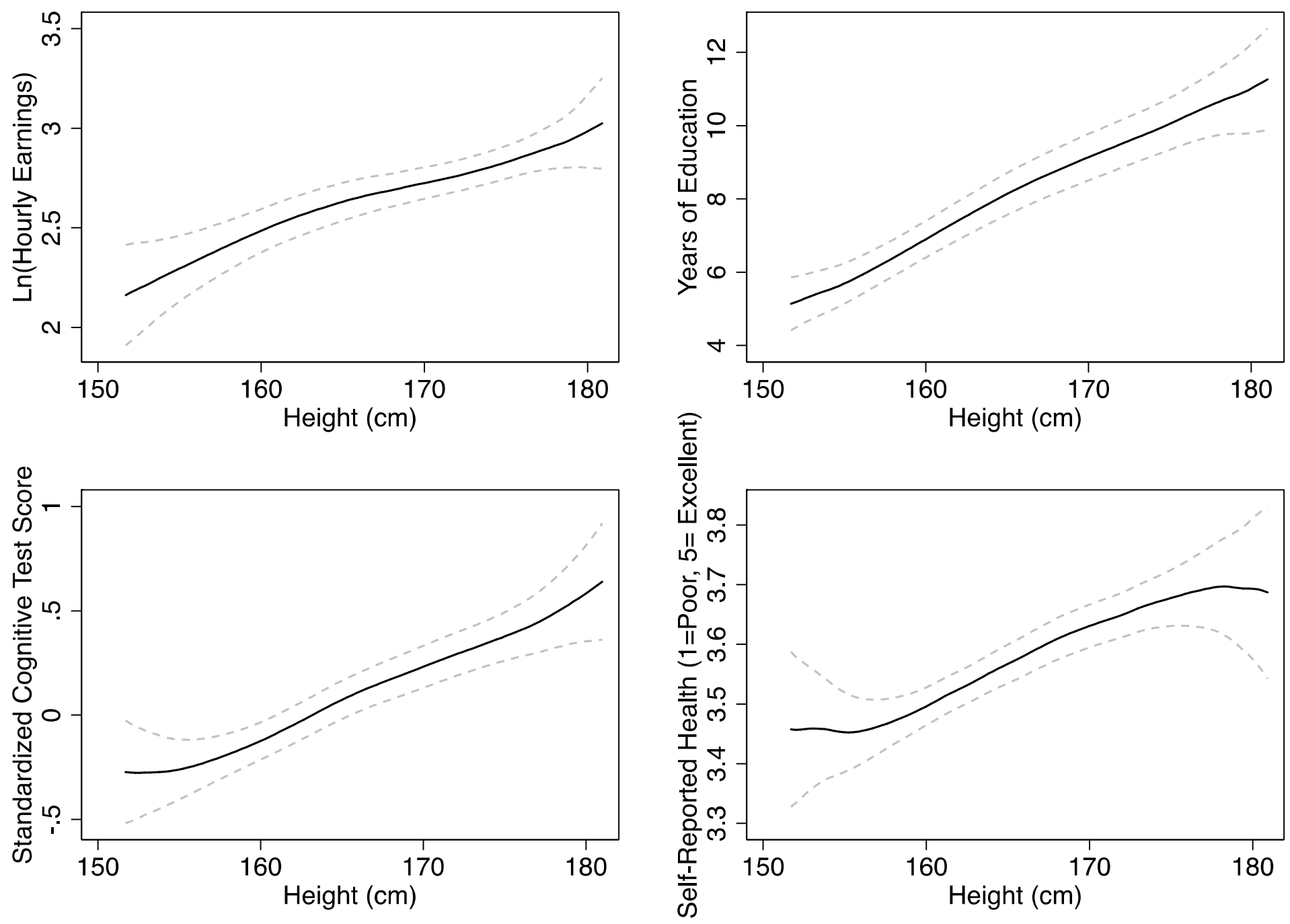

Notes: The panels show local linear regressions with bandwidths of $4 \mathrm{~cm}$; the dashed curves correspond to pointwise 95 percent confidence intervals, block-bootstrapped at the PSU level. All regressions are weighted using sampling weights. The sample includes all men aged 25-65. 
Figure 2: Heterogeneity in the Height-Earnings Relationship
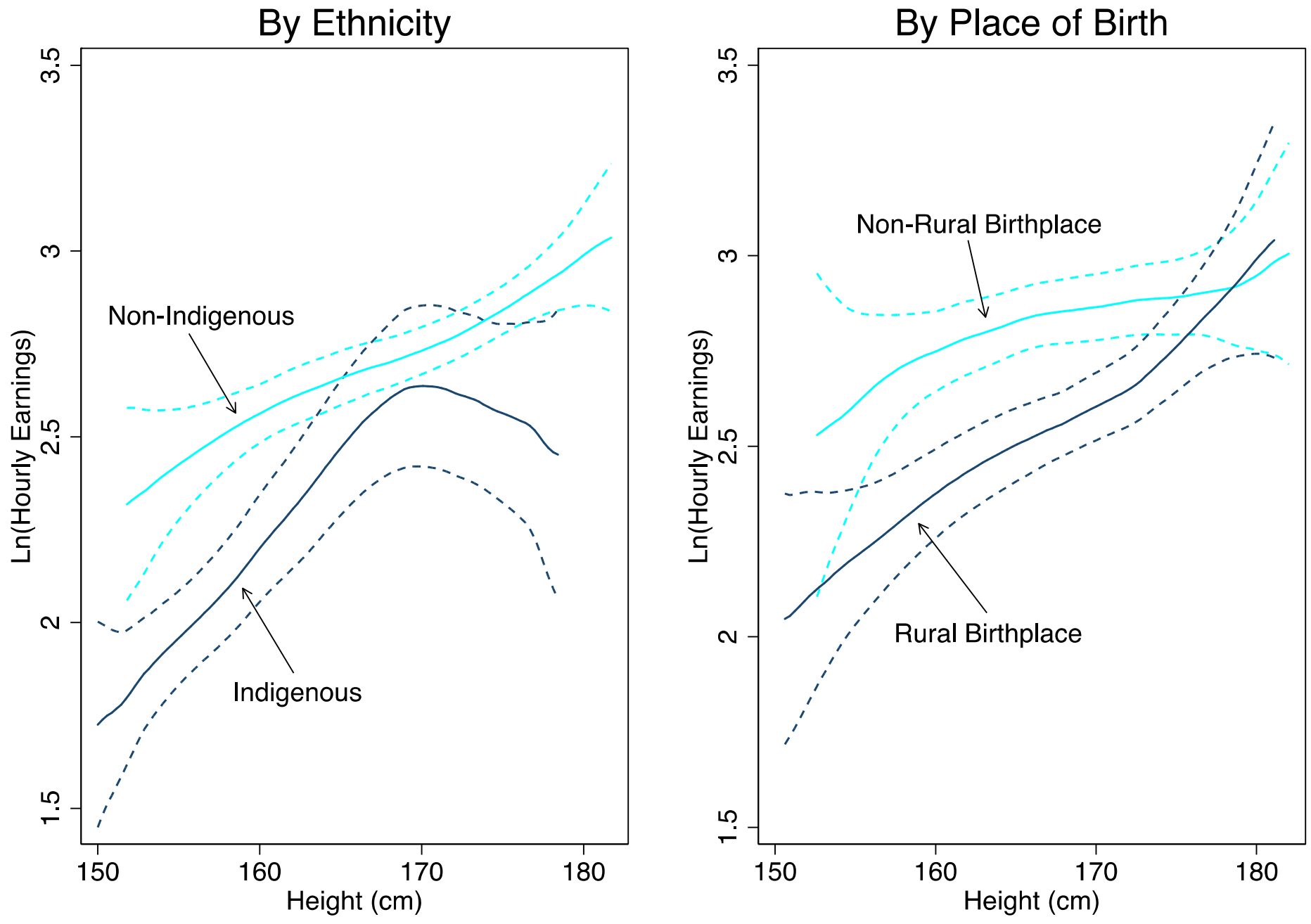

Notes: The panels show local linear regressions with bandwidths of $4 \mathrm{~cm}$; the dashed curves correspond to pointwise 95 percent confidence intervals, block-bootstrapped at the PSU level. All regressions are weighted using sampling weights. The sample includes all men aged 25-65. 


\section{Figure 3: Height and Occupational Skill Requirements}

A. Intelligence
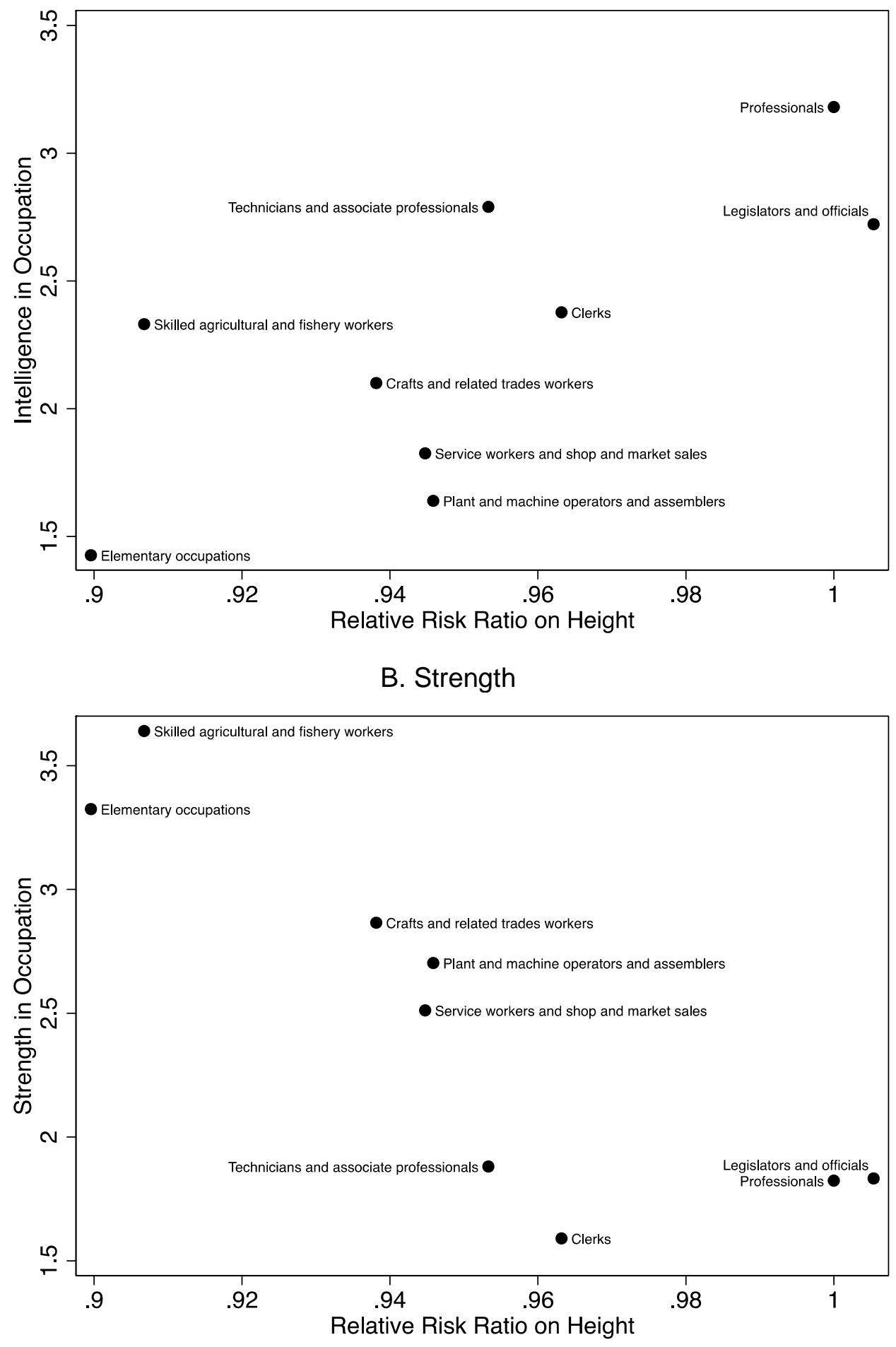

Notes: Figures plot average occupational skill requirements from the Dictionary of Occupational Titles against the relative risk ratio on height from a multinomial logit regression of occupation on height, age, age squared, and an ethnicity dummy. The reference category is "professionals." 
Figure 4: Heterogeneity in the Relationship between Height and Occupational Intelligence Requirements
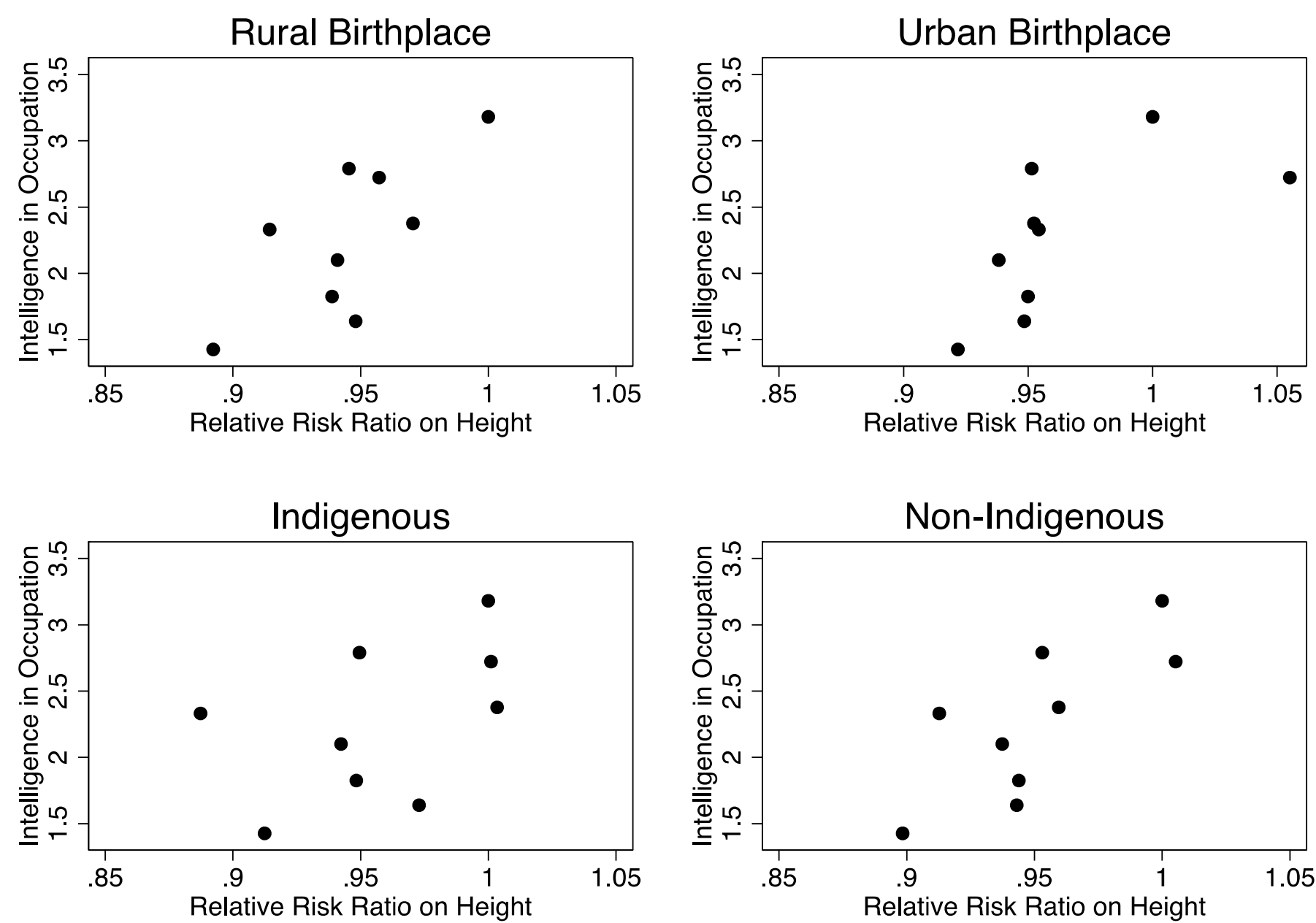

Notes: Figures plot average occupational intelligence requirements from the Dictionary of Occupational Titles against the relative risk ratio on height from a multinomial logit regression of occupation on height, age, age squared, and an ethnicity dummy. The reference category is "professionals." 


\section{Figure 5: Heterogeneity in the Relationship between Height and Occupational Strength Requirements}
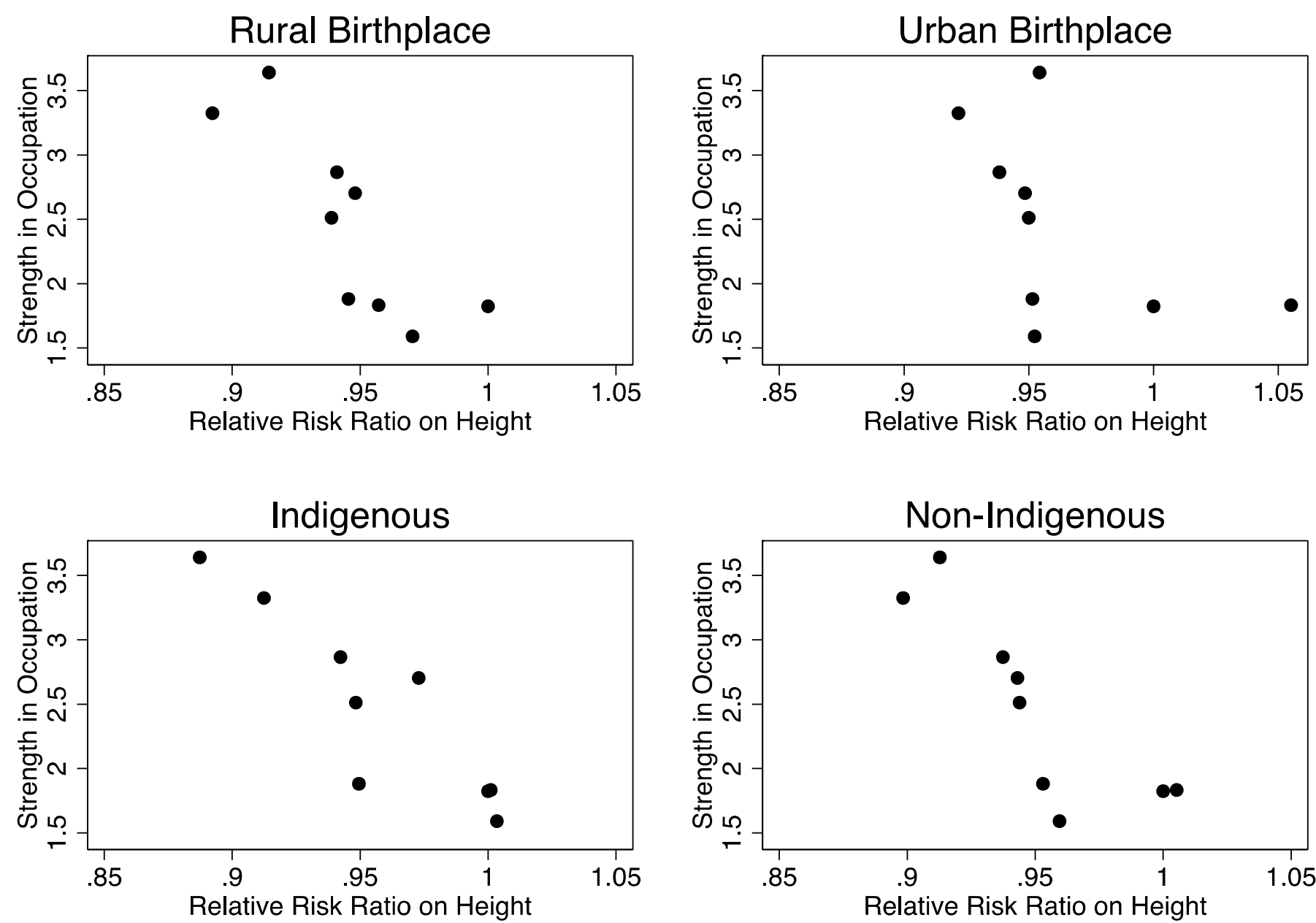

Notes: Figures plot average occupational strength requirements from the Dictionary of Occupational Titles against the relative risk ratio on height from a multinomial logit regression of occupation on height, age, age squared, and an ethnicity dummy. The reference category is "professionals." 
Table 1: Summary Statistics, Men Aged 25-65

\begin{tabular}{|c|c|c|c|c|}
\hline \multirow[b]{3}{*}{ Height (cm) } & \multirow{2}{*}{\multicolumn{2}{|c|}{$\begin{array}{c}\text { Earnings Analysis } \\
(1)\end{array}$}} & \multirow{2}{*}{\multicolumn{2}{|c|}{$\begin{array}{c}\text { Occupational } \\
\text { Choice Analysis } \\
(2)\end{array}$}} \\
\hline & & & & \\
\hline & 165.6 & [6.9] & 165.4 & {$[7.0]$} \\
\hline Raven score & 0.1 & [1.0] & 0.1 & [1.0] \\
\hline Years of education & 8.4 & [4.6] & 8.1 & [4.8] \\
\hline Hourly earnings (2002 Mex\$) & 20.0 & [18.6] & & \\
\hline Brawn occupation & & & 0.89 & \\
\hline Age & 40.1 & [10.3] & 41.0 & [10.5] \\
\hline Indigenous & 0.12 & & 0.15 & \\
\hline Rural residence & 0.20 & & 0.23 & \\
\hline \# of observations & & & & \\
\hline \# of individuals & & & & \\
\hline
\end{tabular}


Table 2: Childhood Conditions, Cognitive Skill, and the Height Premium OLS Estimates, Dependent Variable: Ln(Hourly Earnings)

\begin{tabular}{|c|c|c|c|c|c|}
\hline & \multirow[b]{2}{*}{ (1) } & \multirow[b]{2}{*}{ (2) } & \multirow[b]{2}{*}{ (3) } & \multicolumn{2}{|c|}{ Incl. childhood covariates } \\
\hline & & & & (4) & (5) \\
\hline \multirow[t]{2}{*}{ Height (cm) } & & $0.023^{\star \star \star}$ & $0.020 * \star \star$ & $0.015^{\star \star \star}$ & $0.014^{\star \star \star}$ \\
\hline & & {$[0.004]$} & [0.003] & {$[0.003]$} & {$[0.003]$} \\
\hline \multirow[t]{2}{*}{ Raven score } & & & $0.144^{\star \star \star}$ & & $0.091^{\star \star \star}$ \\
\hline & & & {$[0.021]$} & & [0.018] \\
\hline \multirow[t]{2}{*}{ Indigenous } & $-0.417^{\star \star \star}$ & $-0.313^{\star \star *}$ & $-0.289 * \star \star$ & $-0.192^{\star \star *}$ & $-0.188^{\star \star \star}$ \\
\hline & {$[0.071]$} & {$[0.062]$} & {$[0.061]$} & {$[0.058]$} & {$[0.059]$} \\
\hline \multirow[t]{2}{*}{ Age } & $0.062^{\star \star \star}$ & $0.058^{\star \star \star}$ & $0.053^{\star \star \star}$ & $0.066^{\star \star \star}$ & $0.062^{\star \star \star}$ \\
\hline & [0.013] & [0.012] & {$[0.012]$} & {$[0.012]$} & {$[0.012]$} \\
\hline \multirow[t]{2}{*}{ Age squared } & $-0.0008^{\star \star \star}$ & $-0.0007^{* * *}$ & $-0.0006^{\star \star \star}$ & $-0.0007^{\star \star \star}$ & $-0.0007^{\star \star *}$ \\
\hline & {$[0.0001]$} & {$[0.0001]$} & {$[0.0001]$} & {$[0.0001]$} & {$[0.0001]$} \\
\hline \multicolumn{4}{|l|}{$p$-value on childhood vars. } & $<0.001$ & $<0.001$ \\
\hline Adj. R-squared & 0.039 & 0.070 & 0.096 & 0.146 & 0.156 \\
\hline \multicolumn{6}{|c|}{$\begin{array}{l}\text { Notes: The sample includes } 5,286 \text { observations from } 3,860 \text { men. Brackets contain standard errors } \\
\text { clustered at the PSU-level. Regressions are weighted using sample weights and control for a survey year } \\
\text { dummy. The Raven score is standardized to have a standard deviation of } 1 \text { across the entire Mexican } \\
\text { adult population. The childhood covariates include the father's first job, the father's education, the } \\
\text { mother's education, access to piped water and sanitation at age } 12 \text {, and urban place of birth. To keep the } \\
\text { sample sizes adequate, the specifications that control for childhood covariates also include indicators for } \\
\text { whether these variables are non-missing. The } p \text {-values at the bottom of the table are from joint } F \text { tests of } \\
\text { the coefficients on the actual variables, not the non-missing indicators. }{ }^{*} p<0.10,{ }^{\star \star} p<0.05 \text {, }{ }^{\star \star \star} p< \\
0.01 \text {. }\end{array}$} \\
\hline
\end{tabular}


Table 3: Childhood Conditions, Cognitive Skill, and the Height Premium: Heterogeneity OLS Estimates, Dependent Variable: Ln(Hourly Earnings)

\begin{tabular}{|c|c|c|c|c|}
\hline & \multirow[b]{2}{*}{$(1)$} & \multirow[b]{2}{*}{$(2)$} & \multicolumn{2}{|c|}{ Incl. childhood covariates } \\
\hline & & & (3) & $(4)$ \\
\hline \multicolumn{5}{|c|}{ Indigenous (637 observations, 481 individuals) } \\
\hline \multirow[t]{2}{*}{ Height (cm) } & $0.037^{* \star *}$ & $0.031^{\star \star *}$ & $0.027^{\star \star \star}$ & $0.023^{* * *}$ \\
\hline & {$[0.008]$} & {$[0.007]$} & {$[0.007]$} & {$[0.007]$} \\
\hline \multirow[t]{2}{*}{ Raven score } & & $0.215^{\star \star \star}$ & & $0.185^{\star \star \star}$ \\
\hline & & {$[0.056]$} & & [0.053] \\
\hline \multicolumn{5}{|c|}{ Non-indigenous (4,649 observations, 3,379 individuals) } \\
\hline \multirow[t]{2}{*}{ Height (cm) } & $0.021 * * *$ & $0.018^{\star \star \star}$ & $0.014^{* \star *}$ & $0.013^{* * *}$ \\
\hline & {$[0.004]$} & {$[0.004]$} & {$[0.004]$} & [0.004] \\
\hline \multirow[t]{2}{*}{ Raven score } & & $0.134^{\star * *}$ & & $0.079 * * *$ \\
\hline & & {$[0.021]$} & & [0.018] \\
\hline \multicolumn{5}{|c|}{ Non-urban birthplace (3,521 observations, 2,582 individuals) } \\
\hline \multirow[t]{2}{*}{ Height (cm) } & $0.023^{\star \star *}$ & $0.020 * \star \star$ & $0.017^{\star \star \star}$ & $0.016^{\star * *}$ \\
\hline & {$[0.005]$} & {$[0.005]$} & {$[0.005]$} & {$[0.004]$} \\
\hline \multirow[t]{2}{*}{ Raven score } & & $0.128 * \star \star$ & & $0.083^{\star \star *}$ \\
\hline & & {$[0.027]$} & & [0.024] \\
\hline \multicolumn{5}{|c|}{ Urban birthplace (1,765 observations, 1,278 individuals) } \\
\hline \multirow[t]{2}{*}{ Height (cm) } & $0.015^{\star * \star}$ & $0.015^{\star \star \star}$ & $0.012^{* *}$ & $0.012^{\star *}$ \\
\hline & {$[0.005]$} & {$[0.005]$} & [0.005] & [0.005] \\
\hline \multirow[t]{2}{*}{ Raven score } & & $0.123^{\star \star \star}$ & & $0.096^{\star * *}$ \\
\hline & & [0.030] & & [0.027] \\
\hline \multicolumn{5}{|c|}{$\begin{array}{l}\text { Notes: Brackets contain standard errors clustered at the PSU-level. Regressions are weighted usin } \\
\text { sample weights and control for a survey year dummy. The Raven score is standardized to have } \\
\text { standard deviation of } 1 \text { across the entire Mexican adult population. The childhood covariates include th } \\
\text { father's first job, the father's education, the mother's education, access to piped water and sanitation a } \\
\text { age } 12 \text {, and urban place of birth. To keep the sample sizes adequate, the specifications that control fo } \\
\text { childhood covariates also include indicators for whether these variables are non-missing. }{ }^{*} p<0.10,{ }^{\star \star} \\
<0.05,{ }^{\star \star \star} p<0.01 \text {. }\end{array}$} \\
\hline
\end{tabular}


Table 4: Education, Occupational Choice, and the Height Premium

OLS Estimates, Dependent Variable: Ln(Hourly Earnings)

\begin{tabular}{|c|c|c|c|c|c|c|c|c|}
\hline & $(1)$ & $(2)$ & (3) & $(4)$ & $(5)$ & (6) & $(7)$ & $(8)$ \\
\hline Height & $\begin{array}{c}0.023^{\star \star \star} \\
{[0.004]}\end{array}$ & $\begin{array}{c}0.015^{\star \star \star} \\
{[0.003]}\end{array}$ & $\begin{array}{c}0.013^{\star \star \star} \\
{[0.004]}\end{array}$ & $\begin{array}{c}0.012^{\star \star \star} \\
{[0.003]}\end{array}$ & $\begin{array}{c}0.018^{\star \star \star} \\
{[0.003]}\end{array}$ & $\begin{array}{c}0.014^{\star \star \star} \\
{[0.003]}\end{array}$ & $\begin{array}{c}0.013^{\star \star \star} \\
{[0.004]}\end{array}$ & $\begin{array}{c}0.012^{\star \star \star} \\
{[0.003]}\end{array}$ \\
\hline Raven score & & & & & $\begin{array}{c}0.145^{\star \star \star} \\
{[0.023]}\end{array}$ & $\begin{array}{c}0.046^{\star \star \star} \\
{[0.014]}\end{array}$ & $\begin{array}{c}0.011 \\
{[0.014]}\end{array}$ & $\begin{array}{c}-0.0003 \\
{[0.011]}\end{array}$ \\
\hline Years of education & & & $\begin{array}{l}0.073^{* * *} \\
{[0.006]}\end{array}$ & $\begin{array}{l}0.042^{* * *} \\
{[0.006]}\end{array}$ & & & $\begin{array}{l}0.072 * * \star \\
{[0.005]}\end{array}$ & $\begin{array}{l}0.043^{* * *} \\
{[0.006]}\end{array}$ \\
\hline $\begin{array}{l}\text { Occupation dummies? } \\
p \text {-value on occ. dummies }\end{array}$ & No & $\begin{aligned} \text { Yes } \\
<0.001\end{aligned}$ & No & $\begin{aligned} & \text { Yes } \\
< & 0.001\end{aligned}$ & No & $\begin{aligned} \text { Yes } \\
<0.001\end{aligned}$ & No & $\begin{aligned} \text { Yes } \\
<0.001\end{aligned}$ \\
\hline$R$-squared & 0.070 & 0.226 & 0.205 & 0.252 & 0.096 & 0.229 & 0.204 & 0.253 \\
\hline
\end{tabular}

Notes: The sample includes 5,286 observations from 3,860 men. Brackets contain standard errors clustered at the PSU-level. Regressions are weighted using sample weights and control for year, ethnicity, age, and age squared. The Raven score is standardized to have a standard deviation of 1 across the entire Mexican adult population. The $p$-values at the bottom of the table are from joint $F$ tests of the coefficients on the occupation dummies. ${ }^{\star} p<0.10,{ }^{* \star} p<0.05,{ }^{* \star \star} p<0.01$. 
Table 5: Explaining Occupational Sorting by Height

Logit Marginal Effects, Dependent Variable: $\operatorname{Pr}($ Brawn Occupation), 1 unit $=1 \%$ point

\begin{tabular}{lcccccc}
\hline \hline & $(1)$ & $(2)$ & $(3)$ & $(4)$ & $(5)$ & $(6)$ \\
\hline Height & $-0.627^{\star \star \star}$ & $-0.299^{\star \star \star}$ & $-0.054^{\star \star}$ & $-0.419^{\star \star \star}$ & $-0.229^{\star \star \star}$ & $-0.052^{\star \star}$ \\
& {$[0.104]$} & {$[0.081]$} & {$[0.023]$} & {$[0.082]$} & {$[0.073]$} & {$[0.023]$} \\
Raven score & & & & $-5.80^{\star \star \star}$ & $-3.71^{\star \star \star}$ & -0.198 \\
& & & & {$[0.735]$} & {$[0.567]$} & {$[0.193]$} \\
Years of education & & & $-1.10^{\star \star \star}$ & & & $-1.08^{\star \star \star}$ \\
& & & {$[0.105]$} & & & {$[0.113]$} \\
Childhood covariates? & \multirow{2}{*}{ No } & Yes & No & No & Yes & No \\
$p$-value on childhood vars. & & $<0.001$ & & & $<0.001$ & \\
\hline \hline
\end{tabular}

Notes: The sample includes 7,401 observations from 4,715 men. Marginal effects from logit estimations, evaluated at the means of all independent variables. Marginal effects are multiplied by 100, so that 1 unit equals 1 percentage point. Brackets contain standard errors clustered at the PSU-level. Regressions are weighted using sample weights and control for year, ethnicity, age, and age squared. The Raven score is standardized to have a standard deviation of 1 across the entire Mexican adult population. The childhood covariates include the father's first job, the father's education, the mother's education, access to piped water and sanitation at age 12, and urban place of birth. To keep the sample sizes adequate, the specifications that control for childhood covariates also include indicators for whether these variables are non-missing. The $p$-values at the bottom of the table are from joint Chi-squared tests of the coefficients on the actual variables, not the non-missing indicators. ${ }^{*} p<0.10,{ }^{\star *} p<0.05,{ }^{* \star} p<0.01$. 
Appendix Table 1: Imputed Earnings Regressions

OLS Estimates, Dependent Variable: Ln(Sectoral Earnings Score)

\begin{tabular}{|c|c|c|}
\hline & All Workers & $\begin{array}{c}\text { Workers with } \\
\text { Non-Missing } \\
\text { Earnings } \\
\end{array}$ \\
\hline & (1) & $(2)$ \\
\hline Height (cm) & $\begin{array}{l}0.016^{\star \star \star} \\
{[0.002]}\end{array}$ & $\begin{array}{l}0.014^{\star \star \star} \\
{[0.002]}\end{array}$ \\
\hline Age & $\begin{array}{c}0.033^{\star \star *} \\
{[0.006]}\end{array}$ & $\begin{array}{l}0.039 * \star \star \\
{[0.007]}\end{array}$ \\
\hline Age Squared & $\begin{array}{c}-0.00047^{\star \star \star} \\
{[0.00007]}\end{array}$ & $\begin{array}{l}-0.0005^{\star \star \star} \\
{[0.00009]}\end{array}$ \\
\hline Indigenous & $\begin{array}{c}-0.210^{\star \star \star} \\
{[0.048]}\end{array}$ & $\begin{array}{l}-0.179 * \star \star \\
{[0.050]}\end{array}$ \\
\hline $\begin{array}{l}\text { \# of observations } \\
\text { \#of individuals }\end{array}$ & $\begin{array}{l}7,793 \\
4,930 \\
\end{array}$ & $\begin{array}{l}5,103 \\
3,782 \\
\end{array}$ \\
\hline $\begin{array}{l}\text { Notes: Brackets cor } \\
\text { sectoral earnings } \mathrm{s} \\
\text { occupation-industry- } \\
{ }^{\star \star} p<0.05 \text {, }{ }^{\star \star \star} p<0\end{array}$ & $\begin{array}{l}\text { errors cluster } \\
\text { erage hourly } \\
\text { in the } 2000 \mathrm{M}\end{array}$ & $\begin{array}{l}\text { PSU level. } \mathrm{Tr} \\
\text { in the workel } \\
\text { nsus. * } p<0.1\end{array}$ \\
\hline
\end{tabular}

